\title{
Increasing the Publication of Scientific Articles to Support Key Performance Indicators by Providing Publication Space Facilities in the Petroleum Engineering Department
}

\section{Boni Swadesi ${ }^{1}$, Nur Suhascaryo ${ }^{2}$, Indah Widiyaningsih ${ }^{3}$, Wahyuni $A^{4}$, Yuan Cahyo Guntoro5, Th Laura Octa Daguesta ${ }^{6}$}

1, 2, 3, 4, 5, 6 Department of Petroleum Engineering, Faculty of Mineral Technology, UPN “Veteran" Yogyakarta

\begin{abstract}
This study was used to identify and increase the interest of students of the Department of Petroleum Engineering, Faculty of Mineral Technology, UPN "Veteran" Yogyakarta in publishing scientific articles. the publication of scientific articles has an effect on improving the quality of majors in a university so that it is necessary to support the increase in the publication of scientific articles. The method used in this research is quantitative in the form of socialization, questionnaires, and holding competitions to explore potential interests and talents, as well as awarding student work appreciation. The results obtained from this study are in the form of increasing the quality of publications from competitions conducted with 3 scientific articles with national journal standards and 4 standard posters. From this progress, it is hoped that interest in writing standardized scientific articles will continue to increase, thus the quality of education and achievement of scientific work indicators of a university is achieved.
\end{abstract}

Keywords: Interest, Scientific Articles, increase

This is an open access article under the CC-BY-NC license

\section{INTRODUCTION}

Competitiveness in higher education tends to decrease every year, so that it can threaten the superior position and sustainability of the university concerned. (Retnoningsih, 2013). One focus in the intended competitiveness is scientific articles. Scientific articles are written works designed to be published in a collection of articles or journals, which are written in a scientific writing manner that is in accordance with applicable scientific conventions. (Suyitno, 2011). Scientific articles are very important for students to express their ideas and ideas for human survival in the future, especially in terms of science.

Scientific articles are proven to have a significant impact on the development of science in the world. Several researchers have expressed their opinions in scientific articles both in written form and in the form of written ideas presented in graphic form. Scientific articles are very important in the world of education, both in universities and in terms of research by experts because they are the spearhead of innovation contained in scientific articles.

Currently, the publication of scientific articles for students in the Department of Petroleum Engineering is still very low. The contributing factors are the undeveloped culture of writing scientific articles among students majoring in petroleum engineering, the low willingness and ability to write scientific articles that can be published in quality scientific journals. This means that the dissemination of articles from petroleum engineering students is currently still low. The development of culture and abilities, especially writing motivation, is a challenge and problem that must be addressed immediately. One of the efforts made to encourage the publication of articles for petroleum engineering students in 2021 is to hold socialization in the form of webinars to motivate petroleum engineering students in making scientific articles, provide article publication facilities for petroleum engineering students at UPN "Veteran" Yogyakarta and provide opportunities for students to take part in the scientific article competition. 
UPN "Veteran" Yogyakarta as a university that refers to research for its Main Performance Indicators. The main performance indicators are used by universities to create adaptive universities based on more concrete and tangible outputs.

\section{LITERATURE REVIEW}

A scientific article is a factual or non-fiction essay about a problem published in a journal, magazine, or bulletin with the aim of conveying ideas and facts, in order to convince, educate, and offer solutions to a problem. (Komara, 2017). The characteristics of scientific articles include objective, rational, critical, and reserved. Scientific articles have a formal or standard style of language, so that they focus on science and do not use certain language styles in their writing, citing sources are clear and accompanied by a bibliography.

One of the efforts made is that the academic community in higher education must have a strategy that is able to improve the scientific publications they have (Damalita \& Malang, 2009; Hermanto, 2008; Ningsih, 2015; Sinatra \& Darmastuti, 2009). One of the academicians who play the most role is students (Mopangga, 2014; Riady, n.d.). Because students are the spearhead of the struggle or successors who are able to innovate and be creative in the future. The strategy that must be done is to conduct training to students so that they are able to be effective in improving their quality skills and quantity of scientific publications in universities.

Universities build knowledge management systems and tools to increase the knowledge and insight of leaders, structures, staff, lecturers, and employees. Universities provide work practice facilities to fulfill basic competencies through learning abilities. Universities have access to scientific journals and digital library materials nationally, so it is necessary to conduct training and socialization for librarians and academics. Universities have an effective and efficient management system for facilities and infrastructure by utilizing information technology, including a complete inventory system. The management system also includes a regular reporting pattern from the implementing unit to the management and can be used as information for students and lecturers (Yuliawati, 2012).

Efforts that must be made by universities so that they are able to improve their quality are human resources that must always make a beneficial contribution to the community. One of the efforts that must be made by the academic community in higher education is to conduct scientific publications that are able to provide benefits to every public who reads it. This has been done by various major universities in the world released by Quacquarelli Symonds (QS) World University Ranking such as: University of Oxford (UK), California Institute of Technology (USA), Stanford University (USA), University of Cambridge (United States), and the Massachusetts Institute of Technology (United States) (Symonds, 2015). However, Indonesia is still experiencing big problems because the publications that have been produced are still very low when compared to neighboring countries such as: Malaysia, Thailand, Singapore (Shahjahan \& Kezar, 2013).

\section{RESEARCH METHOD}

This study uses a classroom action research approach (Subadi, 2010). The location of the research was carried out on 18 students of the Department of Petroleum Engineering with different batches. The data collection techniques are through online questionnaires (google forms), interviews, and documentation. While the data analysis is done by descriptive analysis so that the research can be described in a simple way 
The stages of implementation include:

1. Provision of Facilities

Provide facilities or means to provide space for Petroleum Engineering students to support and support the publication of Scientific Articles.

\section{Socialization}

Conducting socialization in order to convey the aims and objectives as well as the description and implementation mechanism of the publication of Scientific Articles to increase the interest of Petroleum Engineering students.

3. Questionnaire

Conduct a survey of student interest in Scientific Articles as a parameter for the continuity of the activities carried out.

\section{Competition}

Creating a competition forum to channel the interests of Petroleum Engineering students and as an award event.

5. Performance Adjustment

Analyzing the results of research that has been carried out as a reference for achieving Key Performance Indicators. 


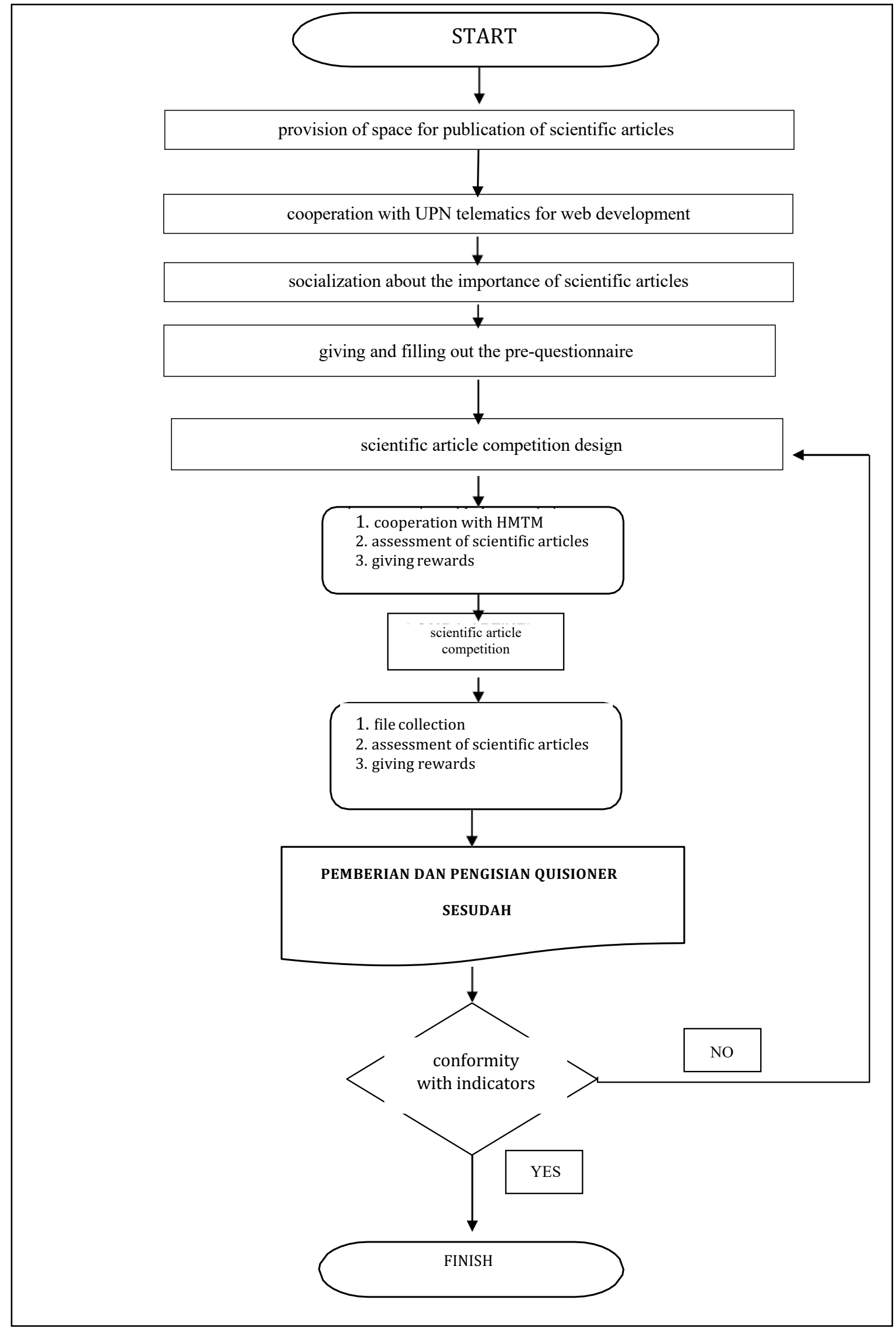

Figure 1. Flow Chart 
RSF Conference Series: Engineering and Technology

Vol. 1 (1), 572-579

Increasing the Publication of Scientific Articles to Support Key Performance Indicators by Providing

Publication Space Facilities in the Petroleum Engineering Department

Boni Swadesi, Nur Suhascaryo, Indah Widiyaningsih, Wahyuni A, Yuan Cahyo Guntoro, Th Laura Octa Daguesta

\section{FINDING AND DISCUSSION}

Provision of Facilities

Facilities and infrastructure are supporting elements in the implementation of the Tri Dharma of Higher Education, which include buildings, furniture, equipment (hardware and software), and asset and campus security systems. The condition of hardware and software infrastructure in universities is still inadequate to support a quality learning process (Yuliawati, 2012).

Providing facilities or means to provide space for Petroleum Engineering students to support and support the publication of Scientific Articles. Provide a special room for publication of scientific articles located in the petroleum engineering building. This room serves to collect, publish, and operate the website with the available computer.

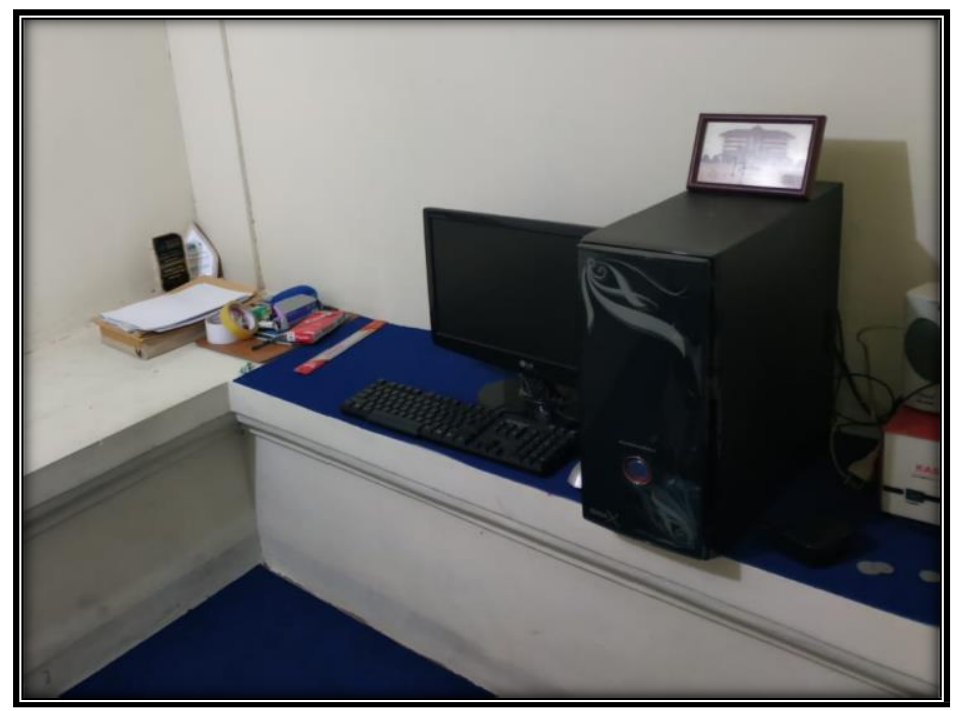

Figure 2. Facilities of scientific articles in petroleum engineering department

Socialization of Scientific Article Publication

This socialization aims to convey the aims and objectives as well as the description and implementation mechanism of the publication of Scientific Articles to increase the interest of Petroleum Engineering students. The provision of material in the form of understanding scientific articles, procedures for compiling scientific articles, criteria for national and international journals, to a journal uploading platform in more detail is given to students.

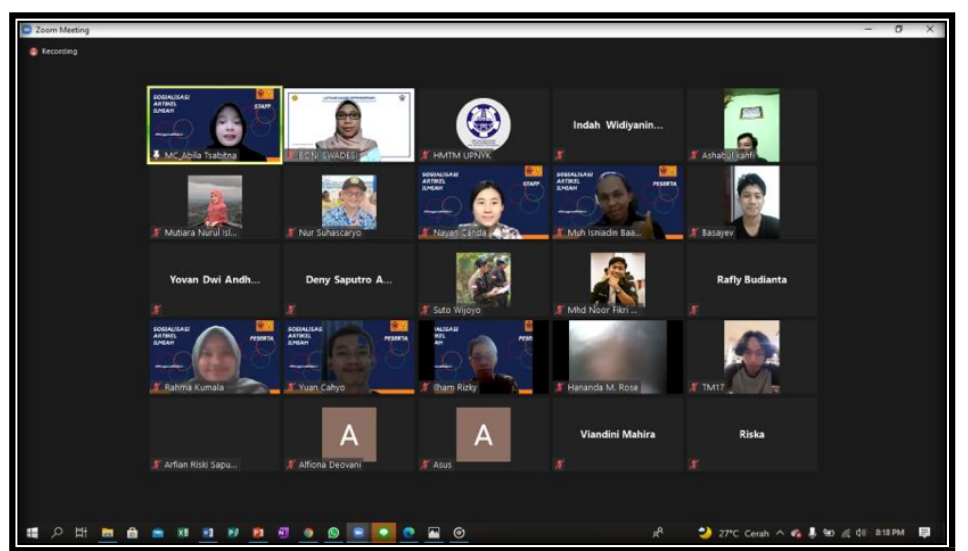

Figure 3. Socialization of scientific articles for petroleum engineering student college with ZOOM meeting

\section{Questionnaire}

This questionnaire aims to determine the interest of Petroleum Engineering students in making scientific articles. Questionnaires were given to students after the socialization was carried out. Based on the results of 18 samples backgrounds from different batches, the graph of interest is obtained as follows: 


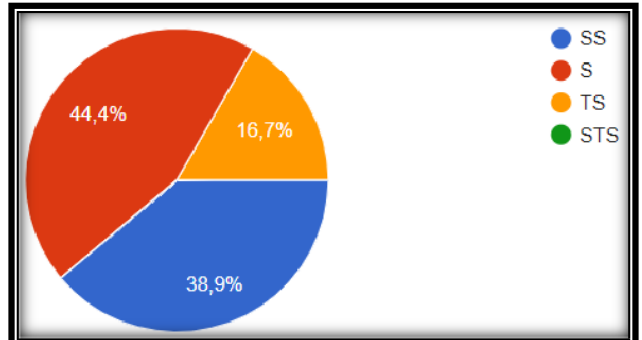

Figure 4. Diagram of the obligation to make scientific articles before competition

Based on the diagram of the obligation to make scientific articles before competition be held, it can be seen that $38.9 \%$ strongly agree, $44.4 \%$ of Petroleum Engineering students agree and $16.7 \%$ disagree. This means that most Petroleum Engineering students agree that students are given the obligation to write a scientific article as a form of implementing lecturelearning.

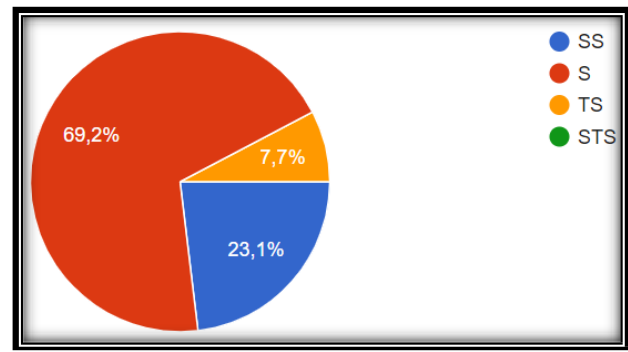

Figure 5. Diagram of the obligation to make scientific articles after competition

Based on the diagram of the obligation to make scientific articles after competition be held, it can be seen that $23.1 \%$ of Petroleum Engineering students strongly agree, $69.2 \%$ agree and $7.7 \%$ disagree. There was an increase in the response of Petroleum Engineering students who agreed with the obligation to write scientific articles as a form of implementing lecture learning.

Competition

Create a competition forum to channel the interest of Petroleum Engineering students and as an award. There are Call For Paper Poster. There were 13 registrants in this competition, which initially targeted at least 10 registrants. The competition round consists of abstract selection, full paper selection, poster presentation and assessment.

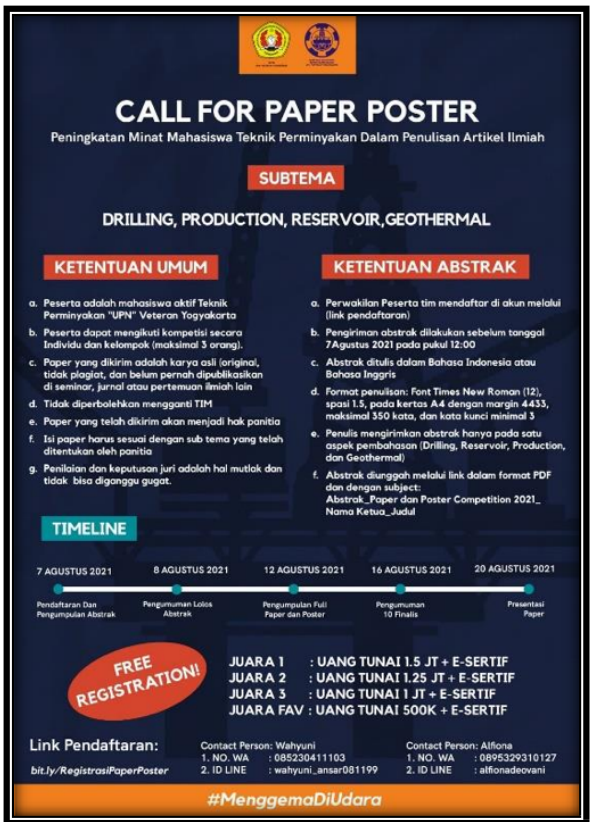

Figure 6. Poster of Call For Paper Poster Competition 
Increasing the Publication of Scientific Articles to Support Key Performance Indicators by Providing

Publication Space Facilities in the Petroleum Engineering Department

Boni Swadesi, Nur Suhascaryo, Indah Widiyaningsih, Wahyuni A, Yuan Cahyo Guntoro, Th Laura Octa Daguesta

Theme

The theme for this scientific article competition is "Increasing Interest of Petroleum Engineering Students in Writing Scientific Articles". Along with the purpose of this research, the theme chosen is expected to be able to balance between increasing publications with new innovations for energy resilience in the present and future.

Round down

The round down of scientific article competition activities starts on August 7, 2021, until August 20, 2021.

Table I. Roundown of Call For Paper Poster Competition

\begin{tabular}{|l|l|l|}
\hline No. & Date & Description \\
\hline 1. & August 7,2021 & Abstract registration and collection \\
\hline 2. & August 8, 2021 & Announcement of passing abstract \\
\hline 3. & August 12,2021 & Full paper and poster collection \\
\hline 4. & August 16, 2021 & Announcement of 10 finalists \\
\hline 5. & August 20,2021 & Paper presentation \\
\hline
\end{tabular}

Reward

There were 4 prizes given to participants in this scientific article competition, including 1st place winner with Rp. 1.500.000 and E-certificate, 2nd prize money Rp. 1.250.000 and E-certificate, 3rd place prize money Rp. 1.000.000 and E-certificate, and the winner of favorite poster with Rp. 500.000 and E-certificate. The winning participant will also be given a prize in the form of publishing a scientific article that he has made on the website of Petroleum Engineering Journal.

\section{CONCLUSION}

Based on the results and discussion, the following conclusions can be drawn:

1. Service research with the title of increasing the interest of Petroleum Engineering students in publishing scientific articles which was carried out in August 2021 has been successful. The training activity lasted for 1 day which was held through the ZOOM application. This success is evidenced by the achievement of the target and the output of the activity in the form of student scientific works that have been successfully published and submitted to nationally accredited journals.

2. The scientific article competition produced 3 papers that met the standards of national journals and 4 posters published on the petroleum engineering journal website.

3. Availability of publication space to support the publication of scientific articles for petroleum engineering students.

4. The success of scientific publication mentoring activities for students in publishing, we hope that mentoring activities can be carried out in a sustainable manner.

5. Assistance activities for scientific publications for students are also expected to foster a writing culture in students, so that in the future the target audience of activities is expected not only to come from students who are completing thesis but also students from the early and middle semesters.

6. Cultivating a writing culture, can also be supported by the lecturers by familiarizing students with reading articles from scientific journals as references in teaching.

\section{Acknowledgements}

The author would like to thank Lembaga Penelitian dan Pengabdian Kepada Masyarakat UPN

"Veteran" Yogyakarta for supporting this research.

\section{REFERENCES}

Damalita, S., \& Malang, A. F. E. U. N. (2009). Pentingnya Manajemen Arsip di Lingkungan Perguruan Tinggi. Jurnal Ekonomi Manajemen.

Fatmawati, Endang. 2017. "Writing Skill Kompetensi dan Publikasi Menuju Visibilitas Lembaga". Makalah disampaikan dalam Semiloka Institution Visibility Based on Open Journal System and Online Academic Writing Skill di Perpustakaan IAIN Salatiga, Kamis, 18 Mei 2017. 
Lukman. 2017. Kebijakan dan Strategi Pengelolaan Jurnal Elektronik. Disampaikan pada Rapat Koordinasi Pengelola Jurnal di Lingkungan BPP Kemendagri dan Pemerintah Daerah, Universitas, serta Kememtrian/Lembaga. Jakarta : Unej Press

Retnoningsih, E 2013, 'Knowledge Management System (KMS) Dalam Meningkatkan Inovasi LPPM Perguruan Tinggi', Akademi Manajemen Informatika dan Komputer BSI Tangerang.

Salam, R, Akhyar, M, Tayeb, Abd., M, Niswanty, R 2017, 'Peningkatan Kualitas Publikasi Ilmiah Mahasiswa dalam Menunjang Daya Saing Perguruan Tinggi', Jurnal Office.

Shahjahan, R. A., \& Kezar, A. J. (2013). Beyond the "National Container" Addressing Methodological Nationalism in Higher Education Research. Educational Researcher, 42(1), 20-29. Sinatra, L., \& Darmastuti, R. (2009). Kajian peran public relations dalam meningkatkan citra perguruan tinggi swasta di jawa tengah. Scriptura, 2(2), 95-105.

Subadi, T. (2010). Lesson Study Berbasis PTK (Penelitian Tindakan Kelas). BP-FKIP UMS.

Yuliawati, Sri. 2012. "Kajian Implementasi Tri Dharma Perguruan Tinggi sebagai Fenomena Pendidikan Tinggi Di Iindonesia", Jurnal Office. 